\title{
RECONHECIMENTO AOS ÍNDIOS DO DIREITO ORIGINÁRIO SOBRE AS TERRAS QUE TRADICIONALMENTE OCUPAM: RAPOSA SERRA DO SOL
}

\author{
Syglea Rejane Magalhães Lopes*
}

\begin{abstract}
Resumo
Este estudo aborda a temática indígena com o objetivo de realizar uma analise comparativa e crítica das normas jurídicas relativas ao reconhecimento do direito ao território por parte dos povos indígenas tomando como referência o Caso da Terra Indígena Raposa Serra do Sol julgado pelo Supremo Tribunal Federal (STF). A abordagem metodológica baseou-se em uma pesquisa teórica, com levantamento bibliográfico, doutrinário, legislativo, das convenções internacionais e da literatura nacional. Os resultados indicam um enfrentamento do STF dos direitos indígenas com base no princípio da unidade. As interpretações resultaram em um novo olhar referente à necessidade de conciliar interesses da nação, orientando quando necessárias restrições.
\end{abstract}

Palavras-chave: Povos Indígenas. Meio Ambiente. Patrimônio ambiental cultural. Raposa Serra do Sol.

\section{Introdução}

O Brasil é um país de dimensão territorial considerável, sendo o quinto colocado em termos continentais. Além disso, seu clima e sua formação geológica colocam-no numa situação vantajosa, porquanto permitem a concentração de diversos ecossistemas e, consequentemente, de uma importante biodiversidade.

É cediço que a biodiversidade mantém uma relação direta com a diversidade cultural e esta, por sua vez, com a sociodiversidade (SANTILLI, 2005). Os povos indígenas, as comunidades remanescentes de quilombos,

\footnotetext{
* Possui Graduação pela Universidade da Amazônia, Mestrado em Direito - Instituto de Ciências Jurídicas - Instituições Jurídicas e Sociais da Amazônia - Direito Ambiental/ Universidade Federal do Pará e Doutorado em Direito - Instituto de Ciências Jurídicas - Direitos Humanos / Universidade Federal do Pará. Coordenadora do Curso de Direito da Faculdade Ideal. Tem experiência na área de Direito Ambiental, com ênfase em Legislação Florestal, Política Ambiental, Responsabilidade Administrativa Ambiental e Povos e Comunidades Tradicionais. syglea@gmail.com
} 
assim como as comunidades extrativistas tradicionais são exemplos dessa simbiose. A Amazônia é, segundo Diegues (2007, p. 6), a região do Brasil que mais concentra essa diversidade - 60\% das populações tradicionais indígenas e não indígenas vivem no bioma amazônico.

Esses sujeitos têm à sua disposição normas jurídicas ambientais, que dão suporte a um sistema regulamentar que ampara a atual concepção de que o bem ambiental cultural compõe o patrimônio ambiental nacional e, consequentemente, garante aos povos e comunidades tradicionais o acesso a territórios tradicionais e uma proteção especial aos bens ambientais localizados em seus territórios.

Há que se ressaltar que a expressão "povos e comunidades tradicionais" só foi utilizada recentemente pela legislação brasileira ${ }^{1}$, por meio do Decreto n. ${ }^{\circ}$ 6.040/07 (BRASIL, 2007). Antes as denominações eram bastante variadas. A título de exemplo, citamos: comunidades tradicionais, populações tradicionais, populações locais, povos tradicionais.

Neste artigo, nos propomos a trabalhar uma categoria específica - os povos indígenas. E verificar a garantia ao território por parte desses povos. Para examinar esta a temática, partimos de duas premissas. De acordo com nossa primeira premissa, o processo de globalização utiliza a cultura como estratégia econômica e política para manter o sistema capitalista. Acreditamos então ser necessário pensar em novas formas de globalização. Para isso, lançamos mão de dois conceitos de Santos (2003) - o cosmopolitismo e o patrimônio comum da humanidade.

Santos (2003, p. 437) assim define o cosmopolitismo:

[...] a solidariedade transnacional entre grupos explorados, oprimidos ou excluídos pela globalização hegemônica. Quer se trate de populações hiperlocalizadas (e.g., os povos indígenas da cordilheira dos Andes) ou hipertransnacionalizadas (e.g., populações deslocadas pela guerra ou por grandes projetos hidrelétricos, imigrantes ilegais na Europa ou na América do Norte), estes grupos vivem a compreensão do espaço-tempo sem terem sobre ela qualquer controle. O cosmopolitismo que defendo é o cosmopolitismo do subalterno em luta contra a subalternização. 
Quanto ao patrimônio comum da humanidade, Santos (2003, p. 437) diz abarcar temas que "[...] só fazem sentido em relação ao globo na sua totalidade [...]". Um exemplo são as questões ambientais, nas quais se incluem os povos e comunidades tradicionais e, portanto os povos indígenas.

De acordo com nossa segunda premissa, os direitos humanos constituem um roteiro emancipatório. Defender essa premissa implica necessariamente, segundo Santos (2003, p. 444), adotar a hermenêutica diatópica e um multiculturalismo progressista.

A hermenêutica diatópica, de acordo com Santos (2003, p. 444), parte do pressuposto de que "[...] os topoi [premissas de argumentação] de uma dada cultura, por mais fortes que sejam, são tão incompletos quanto a própria cultura a que pertencem". Nesse sentido, o objetivo da hermenêutica diatópica é ampliar a conscientização dessa incompletude.

É nesse contexto que nos propomos a estudar o reconhecimento do direito ao território por parte dos povos indígenas. É imprescindível fazer referência à importância do multiculturalismo progressista, por suscitar as questões da diferença, do lugar e dos direitos das minorias em relação à maioria, da identidade e do seu reconhecimento. Daí a importância de utilizar a hermenêutica diatópica, que pressupõe o imperativo transcultural que garantirá a povos e comunidades tradicionais o direito de serem diferentes, pois, caso contrário, a igualdade descaracterizá-los-á.

Portanto, o Poder Público está obrigado a garantir o acesso de povos e comunidades tradicionais aos territórios e a conservar os recursos ambientais localizados em seus territórios; caso contrário, estará contribuindo para o desequilíbrio ambiental. Ora, o equilíbrio do meio ambiente precisa ser garantido, por ser essencial à vida humana digna.

Nesse sentido, o presente estudo objetiva realizar uma analise comparativa e crítica das normas jurídicas ${ }^{2}$ relativas ao reconhecimento do direito ao território por parte de povos indígenas tomando como referência o cordão do Supremo Tribunal Federal referente à Terra Indígena Raposa Serra do Sol, com o intuito de demonstrar que o direito à cultura - em especial, o direito à sociodiversidade - impõe ao Estado o dever de proteger 
os territórios tradicionais por meio de novos institutos e instrumentos que nascem com base no Direito Coletivo.

Essa tarefa suscita algumas questões. É possível se trabalhar com os termos "povos" e "territórios" quando nos referimos aos índios? Como se dá a proteção dos territórios indígenas na Constituição Federal de 1988? Qual a importância da Convenção n. ${ }^{\circ} 169$ para os povos indígenas? Há normas infraconstitucionais de reconhecimento desses territórios? Os institutos criados são capazes de garantir o direito de reconhecimento ao território por parte de povos indígenas? Há restrições a esses territórios por parte dos povos indígenas? As normas são claras quanto aos procedimentos a serem seguidos para identificação, demarcação e homologação das terras indígenas? O que mudou após a decisão do STF no caso da Terra Indígena Raposa Serra do Sol?

Partimos das seguintes hipóteses: a) podemos utilizar os termos "povos" e "territórios", desde que haja clareza quanto a estarmos nos referindo a uma abordagem antropológica; b) a Constituição trouxe proteção específica aos povos indígenas; c) Há normas infraconstitucionais que regulamentam o reconhecimento dos povos indígenas aos seus territórios, mas a maior proteção advém da Constituição Federal de 1988; d) Os institutos criados são capazes de garantir o direito do reconhecimento ao território por parte de povos indígenas; e) A maior parte da doutrina considera não haver restrições aos índios em relação aos seus territórios; f) As normas para identificação, demarcação e homologação das terras indígenas tornaram-se mais claras após a promulgação do Decreto n. ${ }^{\circ}$ 1.175/96, contudo, ainda há aspectos suscetíveis de dúvidas.

Dessa maneira, no que se refere aos objetivos específicos, pretende-se: a) analisar a viabilidade do uso das expressões "povos" e "territórios" referentes aos índios no Direito Brasileiro; b) identificar como se dá o reconhecimento dos territórios indígenas na Constituição Federal de 1988; c) analisar a Convenção n. ${ }^{\circ} 169$ para identificar quais direitos estão resguardados aos índios d) Levantar as normas infraconstitucionais que garantem o reconhecimento aos territórios por parte dos povos indígenas; e) Analisar criticamente os institutos disponíveis para o reconhecimento de 
territórios aos povos indígenas; f) Analisar se os procedimentos a serem seguidos para identificação, demarcação, homologação das terras indígenas são claros; g) Identificar por meio da decisão do STF (BRASIL, 2009) as orientações inovadoras no que se refere ao reconhecimento do acesso aos territórios por parte dos povos indígenas.

De modo geral, a abordagem metodológica do tema baseou-se em uma pesquisa teórica, com levantamento bibliográfico, doutrinário, legislativo, das convenções internacionais e da literatura nacional.

O trabalho encontra-se dividido em oito capítulos. O primeiro capítulo é introdutório. O segundo traz duas considerações preliminares sobre o direito ao território. O terceiro discorre sobre a proteção constitucional dos povos indígenas. O quarto descreve a proteção dos povos indígenas na Convenção 169 da OIT. O quinto apresenta as normas infraconstitucionais que garantem o direito ao território por parte dos povos indígenas. O sexto aborda o reconhecimento do acesso ao território por parte dos povos indígenas. O sétimo traz uma analise do caso da Terra Indígena Raposa Serra do Sol. Por fim, no oitavo capítulo apresentam-se, de forma sintética, as conclusões

\section{Considerações Preliminares Sobre o Direito ao Território por Parte de Povos e Comunidades Tradicionais}

\subsection{Direito ao território no Direito internacional}

Na abordagem do território à luz do direito internacional, é preciso inicialmente destacar os elementos constitutivos do Estado-nação, que, segundo Rezek (2002, p. 153), são três: o território, a população e o governo.

O território está relacionado ao espaço no qual o Estado-nação exerce sua jurisdição ou detém todas as competências para atuar sem que haja concorrência de qualquer outra soberania (RESEK, 2002, p. 153). A população desse Estado soberano é o conjunto das pessoas instaladas em caráter permanente sobre seu território, que inclui uma maioria de súditos locais e uma minoria de estrangeiros residentes. 
Ressalte-se que a comunidade nacional é a dimensão pessoal do Estado soberano (RESEK, 2002, p. 170). E o que faz o indivíduo pertencer à determinada comunidade nacional é o nacionalismo, que nada mais é do que o vínculo entre o Estado soberano e o indivíduo (RESEK, 2002, p. 171).

O terceiro elemento é o governo e está relacionado ao poder político conferido ao Estado para governar. No Brasil, adota-se a forma de governo federativa. A federação brasileira é formada pela União, pelos Estados, pelo Distrito Federal e pelos municípios. Contudo, dentro da federação, apenas um ente terá soberania, os demais dispõem apenas de autonomia. A soberania é concedida ao Estado federal: no âmbito externo, é ele próprio que a exerce, pelo fato de ser pessoa jurídica de direito público externo; quando atua internamente, vê-se representado pela União, que é quem detém o exercício desse poder (FIORILLO; RODRIGUES, 1997, p. 185.).

As demais unidades consideradas autônomas agregam-se sob a bandeira do Estado federal, podendo receber várias denominações: províncias, estados, cantões, repúblicas. Seu grau de dependência em relação ao Estado federal também pode variar, principalmente em relação à União a que pertencem (RESEK, 2002, p. 225).

Os Estados federados não têm personalidade jurídica de direito internacional público; consequentemente, não dispõem de capacidade para manifestar-se conforme sua vontade no cenário internacional (RESEK, 2002).

\subsection{Direito a Territorialidade com base na Antropologia}

Após descrever a interpretação do território com base no Direito Internacional, passamos a examiná-la com base na Antropologia, demonstrando a dificuldade de percepção dos aspectos que a compõem. Para tal desiderato, é importante levantar as dificuldades apontadas pelos estudiosos no uso das expressões "povo" e "território".

Little (2002, p. 6), analisando a dificuldade do Estado brasileiro em reconhecer os territórios sociais dos povos tradicionais como parte da problemática fundiária, aponta como principal obstáculo a relação do 
Estado-nação com o nacionalismo. O nacionalismo está relacionado a um espaço geográfico, para o uso exclusivo dos membros de sua comunidade, e a soberania, que postula a exclusividade do controle sobre seu território, está nas mãos do Estado.

No mesmo diapasão, Souza Filho (1999, p. 121), ao abordar a questão dos povos indígenas, reporta-se à relutância do poder público, de juristas de forma geral e dos tribunais em se referirem às terras indígenas como territórios e aos índios como povo. Isso se dá pelo fato de as expressões "povo" e "território", somadas à soberania, anunciarem um desejo de guerra em nome da liberdade, da independência.

Há também aqueles que buscam dar interpretação ao artigo $4 .^{\circ}$ da Constituição Federal (BRAIL, 1988a), relacionando-o com o Direito Internacional, para justificar por que não se usa o termo "povos" para designar os povos indígenas. De acordo com Maia (1993, p. 255-256), por exemplo, a Constituição Brasileira não empregou a expressão "povos indígenas" porque a palavra "povos", no direito internacional, estaria vinculada ao direito político de um governo próprio e soberano.

Em contrapartida, Souza Filho (1999, p. 80), atento aos aspectos internacionais e nacionais, destaca a necessidade de se observarem os dois entendimentos referentes à autodeterminação, com base no Pacto Internacional sobre Direitos Econômicos, Sociais e Culturais: quando usado por organismos internacionais, o termo "povo" significa povo de um Estado, apesar das diferenças entre os Estados; ao ser usado pelo próprio povo, com base em uma visão antropológica, liga-se à vontade coletiva de um grupo socialmente organizado.

Ademais, complementa esse autor (SOUZA FILHO, p. 71), a diversidade cultural obriga todos ao reconhecimento, principalmente na América Latina, de que não existe país constituído de um único povo, porquanto "[...] cada povo mantém com maior ou menor rigor sua idiossincrasia e sua organização social e jurídica”.

Na mesma senda de raciocínio, Little (2002, p. 20-21) afirma ser um desafio para o Brasil lidar com esse cenário de culturas plurais na esfera territorial e nos âmbito legal, étnico e social. Assim sendo, há necessidade de 
se reconhecer o direito à diferença. O que já tem sido feito, inclusive pelo próprio direito internacional, por meio de tratados internacionais. Por exemplo, o Pacto Internacional sobre Direitos Civis e Políticos (BRASIL, 1992) prevê a obrigação, para Estados onde existem minorias éticas, religiosas ou linguísticas, de respeitar sua vida cultural, respeitando sua religião e suas línguas.

De forma similar, a Declaração sobre os Direitos das Pessoas Pertencentes a Minorias Nacionais ou Éticas, Religiosas e Lingüísticas (ALTO COMISSARIADO DAS NAÇÕES UNIDAS PARA OS DIREITOS HUMANOS), adotada pela Assembléia Geral das Nações Unidas na sua Resolução n. ${ }^{\circ}$ $47 / 135$, de 18 de dezembro de 1992, previu, em seu artigo $2 .^{\circ}$, que as minorias nacionais ou éticas, religiosas ou linguísticas têm direito de desfrutar de sua própria cultura, de professar e praticar sua religião própria e de praticar sua língua livremente, sem que haja discriminação. Referida Declaração (ALTO COMISSARIADO DAS NAÇÕES UNIDAS PARA OS DIREITOS HUMANOS) reconheceu também, em seu artigo $3 .^{\circ}$, que os membros de grupos minoritários podem exercer seus direitos, de modo tanto individual quanto coletivo.

Dessa maneira, verifica-se que, ao tentar garantir seu direito ao território, povos e comunidades tradicionais brasileiros desejam ter, como cidadãos, por parte do Estado-nação soberano o reconhecimento do seu modo de criar, fazer, viver e manifestar sua cultura, sem que seja questionada a legitimidade do Estado soberano (LITTLE, 2002, p. 20).

Em suma, o uso das expressões "povos" e "territórios" para referir-se aos povos e comunidades tradicionais não importam, em hipótese alguma, avocação de soberania, tampouco transformação em Estado. Povos e comunidades tradicionais apenas pretendem ter reconhecido por parte do Estado-nação o seu direito de acesso ao território e aos recursos ambientais para que possam reproduzir-se cultural, social e economicamente.

Conclui-se que inexiste conflito em relação ao uso desses termos, o que há é a necessidade de uma interpretação sistemática das normas que os regulamentam, inclusive dos tratados internacionais ratificados pelo Brasil, que compõem nosso ordenamento jurídico. Portanto, o conflito é apenas 
aparente. Exatamente por isso o Brasil, ao instituir por meio do Decreto n. ${ }^{\circ}$ 6.040/07 (BRASIL, 2007) a política nacional de desenvolvimento sustentável de povos e comunidades tradicionais, inseriu os termos "povos" e "território", demonstrando estar em perfeita sintonia com a abordagem antropológica e com o Direito Internacional.

\section{A Constituição Federal de 1988 e a Proteção aos Povos e Comunidades Tradicionais}

\subsection{Marco Jurídico do Reconhecimento à Diferença}

Até a Constituição Federal de 1988, as normas jurídicas de proteção a povos e comunidades tradicionais foram traçadas de forma fragmentada, ou seja, por categorias. Assim, por exemplo, protegiam-se por meio de normas jurídicas específicas os povos indígenas, as comunidades extrativistas tradicionais: estas por meio da Portaria do INCRA n. ${ }^{\circ}$ 627, de 1987 (INSTITUTO NACIONAL DE COLONIZAÇÃO E REFORMA AGRÁRIA, 1987) aqueles, pela Lei n. ${ }^{\circ} 6.001$, de 1973 (BRASIL, 1973).

A Constituição Federal de 1988 trouxe, por meio da proteção à cultura, o amálgama que faltava para garantir a todos os povos e comunidades tradicionais o direito de se manterem diferentes. É, então, necessário investigar o sentido do termo "cultura" usado pela Constituinte.

Para isso, abeberamo-nos em um estudo de Santos (2005, p.79-88) sobre a tutela das diversidades culturais regionais à luz do sistema jurídicoambiental. A autora informa haver dois sentidos para "cultura". Primeiro, como bem jurídico, ou seja, o direito à cultura, à formação. Segundo, no sentido antropológico, como explica (SANTOS, 2005, p. 81):

[...] os modos de vida, os modelos de conduta, criados, adquiridos e transmitidos para outras gerações no âmbito de um agrupamento humano determinado, materializados através de símbolos, são orientados por uma gama de valores, aceitos pelo grupo social, do que decorre a obrigatoriedade de admitir a inexistência de uma cultura superior, ou melhor do que outra, não sendo permitido privilegiar uma em detrimento de outra, pelo menos diante de uma postura democrática e plural. 
Por isso, compartilha-se a leitura feita por Santos, para quem a Constituição Federal de 88 albergou os dois aspectos do termo cultura. Mas, neste trabalho, enfatizar-se-á o aspecto antropológico, previsto nos artigos 215 e 216 da Constituição, que reconhecem o Brasil como um país pluriétnico e pluricultural.

O reconhecimento dos modos de ser, fazer e viver dos diversos povos e comunidades que contribuíram no processo civilizatório nacional garante o direito à diferença, tanto aos povos indígenas quanto às comunidades remanescentes de quilombos e àquelas oriundas de outros grupos.

Fica assim garantido o direito de serem e de se conservarem como povos e comunidades tradicionais, expurgando-se de vez do sistema jurídico brasileiro qualquer tentativa de integração desses povos e comunidades tradicionais à cultura hegemônica.

Antunes (1998, p. 139-140) ao estudar a principiologia que informa o direito indigenista no Brasil, destaca como um dos princípios a ser seguido o reconhecimento e a proteção, por parte do Estado, da organização social, dos costumes, das línguas, crenças e tradições dos índios originários e existentes no território nacional. Para ele, o significado desse princípio é assegurar aos povos indígenas o direito à diferença. Aceitar a diferença implica aceitar culturas que são diferentes da nossa (1999, p.107).

A interpretação que os referidos doutrinadores fazem dos povos indígenas pode ser estendida aos demais povos e comunidades tradicionais, com base nos artigos 215 e 216 referidos anteriormente.

Conclui-se que, somente após a promulgação da Constituição Federal de 1988, foi possível buscar uma defesa integrada para os povos e comunidades tradicionais por meio do direito à cultura e pela proteção estendida ao patrimônio cultural imaterial, considerado como parte do meio ambiente ecologicamente equilibrado.

\subsection{A Cultura como Bem Ambiental}

A Constituição Federal de 1988 recepcionou a Lei n. ${ }^{\circ}$ 6.938/81 (BRASIL, 1981). Para isso, inseriu um capítulo específico referente ao meio 
ambiente no seu artigo 225, cujo caput garante a proteção ao bem maior que se objetiva proteger, que é o patrimônio ambiental nacional - o meio ambiente ecologicamente equilibrado.

Além disso, referida Constituição deixa claro que o patrimônio ambiental nacional é composto por bens ambientais naturais, artificiais e culturais. Nesse sentido, Fiorillo e Rodrigues (1997, p. 53-64) informam tratar-se de proteção mediata e imediata e indicam a fundamentação jurídica dessa proteção.

Enquanto a proteção do bem maior é mediata e está prevista no caput do artigo 225, os bens ambientais, segundo Fiorillo e Rodrigues (1997, p. 5564), encontram-se protegidos de forma imediata da seguinte forma: os bens ambientais naturais no $\S 1 .^{\circ}$ do artigo 225, incisos I e VII; os bens ambientais artificiais pelo artigo 182 e seguintes, pelo artigo $21, \mathrm{XX}$, e pelo artigo $5 .^{\circ}$, XXIII; os bens culturais nos artigos 215 e 216 e nos artigos 231 e 232, que cuidam de forma específica dos povos indígenas. Acrescentamos o Ato das Disposições Constitucionais Transitórias (ADCT) n. ${ }^{\circ}$ 68, que trata dos remanescentes das comunidades dos quilombos.

No que diz respeito aos bens culturais, verifica-se que o $\S 1 .^{\circ}$ do artigo 215 da Constituição Federal de 1988 impõe ao Estado a obrigação de proteger as manifestações das culturas populares, indígenas, afrobrasileiras, e das de outros grupos participantes do processo civilizatório nacional. Incluiu, portanto, além das culturas indígenas e afro-brasileiras, outros grupos, como, por exemplo, as comunidades extrativistas tradicionais da Amazônia.

Por outro lado, o artigo 216 define patrimônio cultural como os bens de natureza material e imaterial, tomados individualmente ou em conjunto, desde que sejam portadores de referência à identidade, à ação, à memória dos diferentes grupos formadores da sociedade brasileira, nos quais estão incluídas as formas de expressão, os modos de criar, fazer e viver e as criações artísticas, científicas e tecnológicas. Logo, é patente a inserção dos povos indígenas, das comunidades remanescentes de quilombolas e das comunidades extrativistas tradicionais no patrimônio cultural imaterial. 
Houve, portanto, o reconhecimento da diversidade cultural existente no Brasil e a necessidade de harmonizar a convivência de grupos com identidades culturais plurais, reforçando-se a democracia, ao ficar garantido a todos o pleno exercício dos direitos culturais, com base no princípio da cidadania e da dignidade da pessoa humana.

Ademais, os princípios da igualdade e da não discriminação, também adotados pela Constituição Federal de 1988, impedem tratamento discriminatório. O primeiro proíbe a distinção, a exclusão, a restrição ou a preferência com base nas diferenças de raça, sexo, dados culturais ou situações econômicas; já o segundo está relacionado ao direito à diferença, ou seja, ao direito ao reconhecimento da própria identidade cultural.

Infere-se, portanto, com base na interpretação sistemática da Constituição Federal de 1988, que, ao analisar o acesso a territórios por parte de povos e comunidades tradicionais, bem como as relações jurídicas dos bens localizados nesses territórios, está-se abordando o patrimônio ambiental nacional e, consequentemente, os bens que o compõem.

Não resta, assim, dúvida de que povos e comunidades tradicionais encontram-se protegidos como parte do patrimônio ambiental nacional, compondo o patrimônio ambiental cultural imaterial. Para a manutenção desse patrimônio, é imprescindivel que o Poder Público garanta o reconhecimento do acesso aos territórios e aos recursos ambientais localizados nesses territórios.

\subsection{Terras Indígenas na Constituição Federal de 1988}

A Constituição Federal de 1988 trouxe os elementos identificadores da terra indígena. Os mesmos estão dispostos no caput do artigo 231, e $§ 1 .^{\circ}$, que dispõe:

Art. 231. São reconhecidos aos índios sua organização social, costumes, línguas, crenças e tradições, e os direitos originários sobre as terras que tradicionalmente ocupam, competindo à União demarcá-las, proteger e fazer respeitar todos os seus bens.

$\S 1^{\circ}$ - São terras tradicionalmente ocupadas pelos índios as por eles habitadas em caráter permanente, as utilizadas para suas atividades produtivas, as 
imprescindiveis à preservação dos recursos ambientais necessários a seu bem-estar e as necessárias a sua reprodução física e cultural, segundo seus usos, costumes e tradições.

Verifica-se que no caput encontramos o reconhecimento constitucional aos índios do direito originário sobre as terras que tradicionalmente ocupam. Em seguida, no $§ 1 .^{\circ}$ o constituinte fez questão de especificar o que são terras tradicionalmente ocupadas, onde inseriu quatro elementos imprescindíveis: habitação em caráter permanente, utilizadas para suas atividades produtivas; imprescindíveis a preservação dos recursos ambientais; e as necessária a sua reprodução física e cultural, segundo seus usos, costumes e tradições.

Aqui nos servimos da teoria dos círculos concêntricos do ministro Nelson Jobim, para quem o núcleo do primeiro elemento está na expressão "habitadas", que nos informa tratar-se de uma habitação permanente, portanto qualificada, sem qualquer possibilidade de subjetividade.

Referente ao segundo elemento ele indica como central a expressão “atividades produtivas”. Também considerara com grau de objetividade evidente.

O terceiro elemento tem como chave a expressão recursos ambientais, para os quais são agregados segundo o ministro Nelson Jobim três juízos de valor: imprescindibilidade, necessariedade e bem-estar. Nesse caso, considera haver um certo grau de subjetividade, mas são conceitos possíveis de serem averiguados por meio de pesquisa de campo e dados objetivos.

Referente ao último elemento considera chave a expressão; "reprodução física e cultural". Para o ministro Jobin exige o juízo de necessariedade e também um juízo antropológico.

O ministro Jobin considera que o conceito de terra indígena no Brasil é integrado por quatro universos que se interpenetram e se complementam. É quando propõe a utilização da imagem de quatro círculos concêntricos, que bem demonstra a integração e dependência dos elementos que compõe o conceito de terra indígena. E, há ênfase quanto à possibilidade de aferição de cada um desses elementos, com maior ou menor grau de subjetividade, apoiado por estudos antropológicos. 
A grande inovação da teoria dos círculos concêntricos foi buscar desassociar a utilização do advérbio "tradicionalmente" do conceito de posse imemorial e, relacioná-lo com o conceito de formas tradicionais de ocupação. Ainda, que o juízo histórico seja imprescindível a elucidação dos círculos,

principalmente daqueles que se reportam as atividades produtivas e a reprodução física e cultural.

De acordo com essa teoria podemos concluir que a base legal passa a ser o direito originário as terras tradicionalmente ocupadas, desde que preenchidos os elementos dos círculos concêntricos.

A teoria dos círculos concêntricos reforça nossa tese de que a Constituição Federal ao se reportar a terra indígena na verdade está se reportando a território, pois é fundamental assegurar o direito de acesso aos territórios tradicionais, afinal, são eles que, asseguram a reprodução cultural, social e econômica desses povos e comunidades.

Para Almeida (2006, 101-102) a territorialidade "[...] funciona como fator de identificação, defesa e força. Laços solidários de ajuda mútua informam um conjunto de regras firmadas sobre uma base física comum, essencial e inalienável [...]".

\section{A Convenção N. 169 Da OIT e sua Forte Relação com a Garantia dos Territórios para os Povos e Comunidades Tradicionais}

Os tratados internacionais ratificados pelo Brasil que versam sobre direitos humanos estão sendo interpretados, de acordo com decisão do STF, como integrantes do direito constitucional material, por conta do artigo $5 .^{\circ}$, § $2 .^{\circ}$, da Constituição (BRASIL, 1988a). Dessa forma, incluiu-se a abordagem da Convenção n. ${ }^{\circ} 169$ da OIT, da qual o Brasil faz parte, uma vez que esse acordo - que trata sobre povos indígenas e tribais - garantiu o direito desses povos a seus territórios.

Inicialmente, é conveniente identificar os povos indígenas como sujeitos dessa Convenção, presentes na Parte 1, artigo $1 .^{\circ}$, letra “(b)" (BRASIL, 2004a) do item 1, que trata dos povos que já habitavam o país na 
época da conquista ou da colonização, e conservaram suas próprias instituições sociais, econômicas, culturais e políticas.

A referida Convenção traz na Parte II, artigos 13 a 19, o reconhecimento do direito ao território. Embora a Convenção use o termo "terra” em alguns desses artigos, bem como no título da Parte II, refere-se, na verdade, não à terra, mas ao território.

Igualmente, está explícito na Convenção (BRASIL, 2004a), no artigo 13, item 2, que o uso do termo "terras" nos artigos 15 e16 deverá abranger o conceito de territórios, englobando, portanto, a totalidade do habitat das regiões ocupadas pelos povos em questão ou utilizadas de alguma outra forma. O artigo 14, item 1, última parte (BRASIL, 2004a), também reforça a questão da territorialidade, pois faz referência, não somente às áreas que povos e comunidades tradicionais ocupam, mas também àquelas que por eles são utilizadas de outras formas, por exemplo, para caça, rituais religiosos, agricultura.

A Convenção (BRASIL, 2004), em seu artigo 14, item 1, impôs aos Estados-partes o dever de respeitar as terras ou os territórios ocupados ou utilizados de alguma maneira por esses povos e comunidades em função da importância desses espaços para suas culturas, dando ênfase aos aspectos coletivos dessa relação.

A Convenção (BRASIL, 2004) impôs ainda aos Estados-partes, nesse mesmo artigo e item, o dever de reconhecer, para os povos e comunidades tradicionais, os direitos de propriedade e de posse das terras que eles ocupem tradicionalmente e das que não estiverem exclusivamente ocupadas, mas venham sendo utilizadas para o desenvolvimento de suas atividades tradicionais e de subsistência.

Verifica-se aqui também a referência a territórios, e não a terras. O instituto da propriedade e o da posse são considerados pela Convenção como os institutos jurídicos ideais para a garantia desses territórios. Mais à frente, a Convenção passa a tratar esses institutos como direitos, ao impor aos Estados a adequação de medidas que garantam a proteção efetiva desses direitos (propriedade e posse). 
A Convenção proíbe a remoção dos povos e comunidades tradicionais de seus territórios. Essa remoção só poderá ocorrer excepcionalmente. Garante também o respeito às modalidades de transmissão dos direitos sobre a terra, e, se houver previsão de alienação ou de outra forma de transmissão de suas terras, os povos e comunidades tradicionais deverão ser consultados.

Por fim, previu ainda a Convenção o dever de sancionar toda intrusão não autorizada nesses territórios, além de programas agrários em condições equivalentes às das desfrutadas por outros setores, quando as terras não forem suficientes e para que aqueles grupos possam desenvolver-se. Inferese que a Convenção atribuiu ao Estado o papel de guardião dos povos e comunidades tradicionais.

\section{Normas Juridicas Infraconstitucionais que Garantem o Direito ao Território por Parte de Povos e Comunidades Tradicionais}

Atualmente, a norma jurídica que garante a todos os povos e comunidades tradicionais o direito ao território, independentemente da categoria a que pertençam, é o Decreto n. ${ }^{\circ}$ 6.040/07 (BRASIL, 2007a), que regulamentou a política nacional de desenvolvimento de povos e comunidades tradicionais. O objetivo geral dessa política, previsto no artigo $2 .^{\circ}$ desse Decreto, é promover, de forma sustentável, o desenvolvimento dos povos e comunidades tradicionais, reconhecendo, fortalecendo e garantindo seus direitos territoriais, sociais, ambientais, econômicos e culturais, e, ao mesmo tempo, respeitando e valorizando sua identidade, suas formas de organização e suas instituições.

Ademais, um dos objetivos específicos do Decreto n. ${ }^{\circ}$ 6.040/07 é a obrigação de garantir aos povos e comunidades tradicionais seus territórios e o acesso aos recursos naturais que tradicionalmente utilizam para sua reprodução física, cultural e econômica (2007a). Portanto, o Poder Público está obrigado a reconhecer e a garantir o direito aos territórios por parte de povos e comunidades tradicionais. 
Além da proteção geral, algumas categorias receberam proteção especial por meio de leis específicas. Os povos indígenas, pelo Estatuto do Índio, Lei n. ${ }^{\circ}$ 6.001/73 (BRASIL, 1973), que dedicou o capítulo III a este fim - Das Terras dos Índios.

Para o presente trabalho, interessam apenas as terras previstas no capítulo II - Das Terras Ocupadas (OLIVEIRA FILHO, 1987, p. 9). De acordo com o artigo 22 do referido Estatuto, essas terras foram destinadas à posse permanente dos índios. E já à época foram consideradas como bens inalienáveis da União, por meio do parágrafo único do artigo 22.

Por fim, o Estatuto Indígena, em seu artigo 23 (BRASIL, 1973), informou quais seriam essas áreas, conforme descritas a seguir: "Considerase posse do índio ou silvícola a ocupação efetiva da terra, que, de acordo com os usos, costumes e tradições tribais, detém [sic] e onde habita ou exerce atividade indispensável à sua subsistência ou economicamente útil".

Há que se destacar ainda o Decreto n. ${ }^{\circ}$ 1.775/96 (BRASIL, 1996), que passou a dispor integralmente sobre os procedimentos administrativos de reconhecimento do acesso ao território por parte dos povos indígenas.

\section{Reconhecimento do Acesso ao Território por parte dos Povos Indigenas}

\subsection{Institutos e Instrumentos Jurídicos que Garantem o Acesso ao Território por Parte de Povos Indígenas}

O arranjo jurídico construído para garantir o acesso ao território por parte dos povos indígenas foi inovador (MENDES, 2002, p. 13). Por isso provocou muitas reflexões no âmbito jurídico, principalmente com foco em dois institutos tradicionais do direito civil: a propriedade e a posse, que passaram a ser confrontadas com o direito originário e com a posse permanente.

Os doutrinadores advertem que não se pode comparar a posse permanente dos índios com a posse civil. Para Silva (1999), quando a Constituição refere-se à posse permanente, não o faz como um pressuposto de volta ao passado; ao contrário, protege as terras indígenas para o futuro, tornando-as inclusive inalienáveis e indisponíveis. O autor complementa, 
afirmando que a Constituição assim faz com base no direito originário, ou seja, a posse é permanente porque preexiste à posse mesma.

Ademais, no que diz respeito ao direito de propriedade, a Constituição Federal de 88 declarou, por meio do artigo 20, inciso XI (BRASIL, 1988a), que as terras indígenas seriam de propriedade da União. Contudo, embora a União seja a proprietária das terras indígenas, delas não poderá usar, gozar, nem dispor, porquanto seu uso e seu gozo pertencem aos povos indígenas de forma permanente, trata-se de destinação constitucional.

Não obstante, verifica-se que os povos indígenas, apesar de poderem usar e gozar dessas terras, delas também não poderão dispor, por não serem proprietários, também não poderão transferir a posse, salvo por hereditariedade, entendida como uma decorrência da condição de ser índio e não da sucessão em si. Essas medidas foram tomadas a fim de proteger seus territórios pelo fato de eles serem imprescindiveis ao desenvolvimento econômico, social, cultural e ambiental dos povos indígenas.

Observa-se a complexidade do arranjo jurídico para garantir os territórios dos povos indígenas. Santilli (1999, p. 45) afirma, por exemplo, que as terras indígenas são terras públicas com finalidades especiais, assumindo, portanto, serem de propriedade da União.

Tourinho Neto (1993, p. 39) considera que as terras indígenas são bens públicos dominicais, por estarem incluídas nos bens da União no artigo 20 da Constituição. Como bens públicos, são imprescritíveis, impenhoráveis e não sujeitas a usucapião ou a qualquer oneração, como dispõe o artigo 231, § 4. ${ }^{\circ}$, da Constituição Federal.

Souza Filho (1999, p. 123) considera tratar-se de uma relação jurídica diferente da convencional estabelecida pelo direito civil. Para ele, a terra indígena não é terra pública nem privada, também não se encaixa no direito de propriedade.

A posse permanente garantida aos indígenas em relação a essas terras também difere das posses que compõem o ordenamento jurídico brasileiro, conhecidas como posse civil $^{3}$ e posse agrária ${ }^{4}$, conforme fundamentação doutrinária, a qual passamos a explanar. 
É cediço que a Constituição, ao reconhecer os direitos originários em relação às terras indígenas, admite tratar-se de direitos anteriores à criação do Estado brasileiro5. Contudo, as críticas à posse permanente dos povos indígenas foram reforçadas ao se contrapor o direito originário deles ao instituto da posse civil e até da posse agrária. Sustenta-se que o direito originário dos índios está relacionado, não ao direito de propriedade, mas à territorialidade. A posse permanente possui seu fundamento no direito originário, e não na propriedade, diferindo, por isso, da posse civil e da posse agrária, ambas fundadas no direito de propriedade privada.

As posses civis e agrárias, de acordo com sua regulamentação, necessitam de legitimação, pois só se pode ter a posse dos bens que nunca tiveram dono ou daqueles que foram abandonados pelo antigo dono. Como a posse permanente possui seu fundamento no direito originário6, claro está que não se poderá falar de legitimidade, porque se estão falando de terras que sempre tiveram donos - os povos indígenas (BENATTI, 2003).

Outra distinção citada por Souza Filho (1999, p.123) é o fato de a posse permanente poder ser usufruída coletivamente, enquanto as demais serão usufruídas individualmente, ou seja, com exclusividade.

Nota-se que a Constituição de 88 criou novos institutos jurídicos para resguardar direitos coletivos, distintos, portanto, dos demais, criados para regulamentar relações privadas. Nesse sentido, não há como encontrar no direito civil ou mesmo no direito agrário amparo para essa nova realidade. Por isso, muitas vezes os doutrinadores referem-se a esses novos institutos como sui generis, por fugirem às regras desenhadas para as relações jurídicas privadas.

Por essa concepção, sustenta-se que nem o direito originário é direito de propriedade, nem a posse permanente poderá ser comparada às demais posses. Quando se reconhece que as terras indígenas são bens da União, elas devem ser entendidas como bem público registrado no nome da União. Contudo, de todos os direitos relacionados à propriedade, o único que sobreviveu foi o de reivindicar as terras de quem as detenha injustamente. Nesse sentido, concorda-se com Sousa Filho, para quem as terras públicas 
não se enquadram em nenhuma das categorias existentes ${ }^{7}$, pois se trata de uma categoria de terra pública especial.

Isso se deu pelo fato de a Constituição Federal de 88 ter inserido direito de igual valor - o direito originário sobre as terras que tradicionalmente os povos indígenas ocupam - e ter destinado tais terras a sua posse permanente. Ainda que a Constituição Federal tenha reconhecido as terras indígenas como de propriedade da União, impôs a esta a obrigação de garantir o uso e o gozo aos povos indígenas, com base no direito originário. Por isso, os povos indígenas poderão usufruir de suas terras, por meio de um novo instituto criado com o objetivo de atender a essa peculiaridade - a posse permanente. Esse novo instituto concretizar-se-á com base no usufruto indígena; logo, o direito à territorialidade está garantido.

O direito originário dos índios sobre as terras que tradicionalmente ocupam garante o direito ao território e faz com que sejam nulos e extintos, não produzindo efeitos jurídicos, os atos que tenham por objeto a ocupação, o domínio e a posse das terras indígenas, conforme previsão no artigo 231, § 6. ${ }^{\circ}$, da Constituição Federal (BRASIL, 1988).

Além disso, a Constituição, em seu artigo $231, \S 5 .^{\circ}$ e $\S 6 .^{\circ}$, garante também aos grupos indígenas a sua não remoção de suas terras, salvo ad referendum do Congresso Nacional, apenas em caso de catástrofe ou de epidemia, desde que ponha em risco sua população, ou no interesse da soberania do País, após deliberação do Congresso Nacional. Cessado o risco, é garantido o seu retorno imediato (BRASIL, 1988).

Nesse caso, além de afastar o receio de alguns, quanto à integridade do território nacional, garantiu os direitos primários dos índios em relação aos seus territórios e ainda obrigou a União a garantir o uso e o gozo aos índios por meio da posse permanente e do usufruto indígena.

Impôs também à União a obrigação da defesa desses territórios, segundo Márcio Santilli (1999), tanto pela obrigação de defender os povos indígenas, quanto pela obrigação de defender seu próprio patrimônio.

Além disso, sustenta-se que essa proteção está diretamente relacionada à obrigação do Poder Público em relação ao patrimônio 
ambiental nacional - o meio ambiente ecologicamente equilibrado -, porque composto pelo bem ambiental cultural, do qual povos e comunidades tradicionais fazem parte. E a sobrevivência desses povos está diretamente relacionada à proteção dos seus territórios.

Márcio Santilli (1999) considera que o fato de outros países garantirem o direito de domínio e de posse das terras indígenas aos povos indígenas não os coloca em melhores condições, pois, quando o constituinte declarou que as terras indígenas são inalienáveis, fez com que diluísse consideravelmente a diferença entre domínio e posse permanente. Ademais, tornou essas terras indisponíveis e os direitos sobre elas, imprescritíveis.

Infere-se, portanto, que o Brasil foi criativo no arranjo jurídico em relação aos povos indígenas, utilizando inclusive institutos distintos dos sugeridos pela Convenção n. ${ }^{\circ} 169$ da OIT, porém de importância igual ou superior ao previsto na Convenção. O arranjo jurídico brasileiro é de igual importância porque a essência da proteção inserida na Convenção é garantir a esses povos o acesso ao território, e o Brasil o fez, estando obrigado a reconhecer os territórios e a destiná-los para sempre aos povos indígenas. O arranjo jurídico brasileiro superou o previsto na Convenção ao ter tornado esses territórios indisponíveis, ou seja, retirou-os do mercado e exterminou de vez a estratégia de integração desses povos à cultura hegemônica. Ainda, ao manter o domínio, o Brasil também estará obrigado a cuidar desse patrimônio, que é ao mesmo tempo seu (público), dos povos e comunidades tradicionais (coletivo) e de toda a humanidade (difuso).

\subsection{Procedimentos Administrativos de Reconhecimento às Terras Indígenas por parte dos Povos Indígenas}

O órgão competente para regularizar a situação fundiária das comunidades indígenas é a FUNAI. O processo administrativo de reconhecimento dá-se em quatro fases: identificação, demarcação, homologação e registro (1996a).

A identificação exige estudo, que será realizado por um grupo de técnicos especializados, coordenado por um antropólogo e composto 
preferencialmente por funcionários da FUNAI. Eles elaborarão um relatório que será encaminhado ao presidente da FUNAI, o qual poderá desaprová-lo; para isso terá de fundamentar sua decisão e também prescrever diligências a serem realizadas no prazo máximo de 90 dias.

Caso o relatório seja aprovado pelo presidente, ele terá o prazo de 15 dias para publicar um resumo do relatório no Diário Oficial da União (DOU) e no Diário Oficial da unidade federada, devendo também afixar um documento na sede da prefeitura local.

Do início desse procedimento até 90 dias após a publicação do relatório, todo interessado poderá manifestar-se sobre ele. Encerrado esse prazo, a FUNAI terá 60 dias para elaborar pareceres sobre as manifestações e posteriormente deverá encaminhar o processo ao ministro da Justiça.

O ministro da Justiça terá o prazo de 30 dias para publicar portaria declarando os limites da terra indígena e determinando à FUNAI sua demarcação, que promoverá a demarcação física da área e em seguida encaminhará os procedimentos ao presidente da República, para homologação.

A homologação deverá ser feita por meio de decreto, no prazo de 30 dias. Por fim, o processo retorna à FUNAI, que terá o prazo de 30 dias após a homologação para realizar o registro da terra indígena no Cartório de Patrimônio da União (CPU) e no cartório do imóvel da comarca.

\subsection{Procedimento para Remoção de Terceiros Ocupantes de Terras Indígenas Declaradas}

A remoção de terceiros ocupantes de terras indígenas declaradas é um procedimento paralelo ao processo formal de reconhecimento do direito territorial indígena. O Governo está obrigado a retirar terceiros que estejam ocupando esses territórios, ainda que de boa-fé.

Caso a ocupação seja comprovadamente de boa-fé, caberá aos ocupantes indenizações por parte do Governo pelas benfeitorias que tenham realizado. Esses cálculos incluirão somente as benfeitorias, jamais poderão incluir valores da terra ou dos títulos, pois, conforme previsão 
constitucional, os índios têm direito originário às terras tradicionalmente ocupadas, portanto anteriores ao próprio direito. Além disso, essas ocupações são consideradas como atos nulos pela própria Constituição.

O procedimento para a retirada de terceiros tem início ainda no processo de identificação das terras indígenas por meio do levantamento cadastral e cartorial e com a avaliação das possíveis benfeitorias desses ocupantes de boa-fé para fins de indenização.

Existe na FUNAI uma Comissão de Sindicância Permanente, encarregada de aferir se a ocupação é de boa-fé, ou seja, antiga - de preferência anterior à portaria declaratória ou à divulgação dos estudos da FUNAI -, se é pacífica e se não foi fruto de esbulho ou conseguida por qualquer procedimento condenável.

Com a publicação da Portaria Declaratória do ministro da Justiça, a FUNAI está apta a proceder ao pagamento das indenizações devidas aos ocupantes de boa-fé, que terão o prazo de 60 a 120 dias para retirar-se da terra indígena. Os que forem considerados clientes da reforma agrária terão direito a reassentamento pelo INCRA.

\section{O Caso Terra Indigena Raposa Serra do Sol: Direitos e Restrições}

Embora haja previsão legal do direito originário dos povos indígenas sobre as terras que tradicionalmente ocupam e mesmo considerados nulos os atos que tenham por objeto a ocupação, o domínio e a posse dessas terras, verificam-se sérios conflitos levados ao Poder Judiciário. O caso Terra Indígena Serra do Sol retrata mais um desses conflitos, que por ter natureza federativa do conflito entre partes, deflagrou a incidência da competência do Supremo Tribunal Federal (STF).

Utilizamos este caso para analise pelo fato do mesmo ter tido repercussão nacional e principalmente pela inovação nos argumentos e orientações encaminhadas pelo STF referente não apenas a este caso, mas a futuras interpretações relacionadas ao reconhecimento aos índios do direito originário das terras que tradicionalmente ocupam. Embora o caso verse também sobre aspectos relacionados a uso de recursos ambientais, 
arrendamento, o artigo será concentrado nos aspectos referentes ao direito dos índios sobre seus territórios. A petição que deu origem a Ação Popular foi a de n. ${ }^{\circ} 3.388$ RORAIMA.

\subsection{Considerações Preliminares ao Não Uso das Expressões "Povos" e “Territórios"}

Verificou-se nos argumentos utilizados pelo STF que não houve por parte dos nossos legisladores o emprego da expressão povo e território para que não pairassem dúvidas sobre a utilização do referido termo, pois quando empregados para se reportar ao Estado-nação indica poderes políticos no âmbito externo, ou seja, internacional.

Contudo, verifica-se claramente que referidos termos possuem significados distintos, conforme abordado no item 2 deste artigo ao se reportar a aspectos políticos-jurídicos estamos abordando sobre os componentes do Estado brasileiro e, quando usado para se reportar ao índios estamos nos referindo a aspectos antropológicos.

Nesse sentido, não são poucas as vezes que os próprios ministros fizeram referência as terras indígenas como territórios, assim como o próprio Decreto n. ${ }^{\circ}$ 6.040/2007 reportou-se ao termo território, tendo inclusive definido seu significado. Até mesmo a Convenção 160 da Organização Internacional do Trabalho (OIT) também traz referência aos dois termos, terra e território. Portanto, não há dúvidas quanto à possibilidade de utilização desses termos com conotações totalmente díspares, com seus significados claros.

\subsection{Teoria do Fato Indigena como Base Para Identificação das Terras Indigenas}

O ministro Direito trabalha a teoria do fato indígena. Reporta-se aos mesmos elementos da teoria dos círculos concêntricos do ministro Nelson Jobim. Contudo, trabalha os elementos como fatos possíveis de serem comprovados por meios de métodos científicos, utilizados pela antropologia. A 
comprovação científica dos fatos é que dará ao Poder Público a base para identificação e demarcação das terras indígenas.

De acordo com o ministro para a teoria do fato indígena basta a comprovação dos quatro elementos, dispensando considerações sobre a ocupação imemorial, uma vez que a constituição inseriu um marco temporal o ano de sua promulgação. Para o ministro deve-se fazer essa diferença, pois há que se comprovar uma presença constante e persistente nessas terras. E mais, terras abandonadas não são consideradas como indígenas, conforme súmula n. ${ }^{\circ} 650$ do STF. A referida teoria segundo seu autor "dispensa considerações sobre a idade da ocupação, exige, repito, a demarcação da presença constante e persistente dos índios na área em questão, o que é tarefa dos documentos produzidos no processo de regularização." (BRASIL, 2009, p. 385).

Verifica-se que o ministro Direito seguiu a mesma linha de raciocínio do ministro Nelson Jobim, que buscou desassociar a utilização do advérbio "tradicionalmente" do conceito de posse imemorial e, relacioná-lo com o conceito de formas tradicionais de ocupação. Ainda, que o juízo histórico seja imprescindivel a elucidação dos círculos.

Sob essas argumentações ele propõe a utilização da teoria do fato indígena em substituição a teoria do indigenato. Segundo o ministro esta escolha "prestigia a segurança jurídica e se esquiva das dificuldades práticas de uma investigação imemorial da ocupação indígena.” (BRASIL, 2009, p. 381).

Levando em consideração a necessidade da utilização de métodos científicos da antropologia para identificação das terras tradicionalmente ocupadas pelos povos indígenas e tendo como referência a comprovação dos fatos o ministro Direito considera necessária a participação de pelo menos três antropólogos nesse processo. Seria uma forma de evitar que a préconcepções pessoais de um único antropólogo possa influenciar todo o trabalho. Também considera a presença de outros especialistas nesta comissão importante objetivando enriquecer e dar maior sustentação científica aos estudos. 


\subsection{Procedimentos de Identificação, Reconhecimento, Demarcação e Registro das Terras Indigenas}

Alguns aspectos foram questionados quanto a esses procedimentos que merecem analise.

\subsubsection{Indiscutivel Constitucionalidade do Decreto n. ${ }^{\circ} 1.775 / 96$}

Não foram poucas as ações judiciais que buscaram a declaração da inconstitucionalidade do Decreto n. ${ }^{0}$ 1.775/96. Este decreto substituiu o Decreto n. ${ }^{\circ} 22 / 91$ pelo fato deste não ter trazido a previsão para ampla defesa e contraditório no processo administrativo de demarcação das terras indigenas.

Portanto o Decreto n. ${ }^{\circ}$ 1.775/96 objetivou sanar referida lacuna, tendo inclusive estendido o prazo aos interessados nas demarcações de terras indígenas em curso, cujo decreto homologatório ainda não tivesse sido objeto de registro em cartório imobiliário ou na Secretaria do Patrimônio da União (SPU) do Ministério da Fazenda, concedendo-lhes o prazo de 90 (noventa) dias para manifestação em procedimento administrativo.

Assim, para o STF não há que se falar em inconstitucionalidade do Decreto n. ${ }^{\circ}$ 1.775/96, citamos como exemplo, algumas decisões recentes, tais como: em 2001 o Mandado de Segurança n. ${ }^{\circ}$ 21.892-4 - Mato Grosso do Sul; em 2004 o Mandado de Segurança n. ${ }^{\circ} 21.660-3$ - Distrito Federal, em 2005 o Mando de Segurança n. ${ }^{\circ}$ 24.045-8 - Distrito Federal; em 2007 o Mandado de Segurança n. ${ }^{\circ}$ 21.896-7 - Paraíba; em 2010 a Tutela Antecipada - Referendo na Ação Civil Originária n. ${ }^{\circ} 1.383$ - Mato Grosso do Sul; em 2011 Recurso Ordinário em Mandado de Segurança n. ${ }^{\circ} 26.212$ - Distrito Federal.

Em destaque fazemos referência para o Mandado de Segurança n. ${ }^{\circ}$ 25.483-1 - Distrito Federal para o ao ano de 2007, por dizer respeito à Terra Indígena Raposa Serra do Sol, quando também se posiciona favoravelmente a constitucionalidade do Decreto $n .^{\circ} 1.775 / 96$. Dessa forma, não assiste razão ao autor da Petição n. 3.388 - Roraima em 2009, incluir como parte de seu pleito na Ação Popular referente à Terra Indígena Raposa Serra do Sol a 
inconstitucionalidade do decreto em questão. Tendo sido indeferido seu pleito, trata-se de decisão pacífica no STF a constitucionalidade do mesmo.

\subsubsection{Admissibilidade de Divergência de Áreas entre a Portaria e o Decreto}

Conforme abordado no item 6.2. deste artigo dentre os procedimentos 92 de identificação das terras indígenas consta o momento em que o ministro da Justiça de posse do relatório e tendo aprovado o mesmo, terá o prazo de 30 dias para publicar portaria declarando os limites da terra indígena $\mathrm{e}$ determinando à FUNAI sua demarcação.

A demarcação física da área que fica sob a responsabilidade da FUNAI, uma vez concluída deverá ser encaminhada ao presidente da República, para homologação.

No caso da Terra Indígena Raposa Serra do Sol o autor da Ação Popular questiona a divergência na área prevista na Portaria que declarou os limites da referida terra indígena e no Decreto que a homologou.

Contudo, referido questionamento também não é novo, pois ainda no ano de 2007 houve questionamento similar ao STF por meio do Mandado de Segurança n. ${ }^{\circ}$ 21.896-7 - Paraíba. Na ocasião, a questão foi amplamente discutida e esclarecida, tendo resultado no seguinte entendimento do STF: “1. No que tange à declaração dos limites e superfície da terra indígena a ser demarcada, é possível haver diferença entre área e perímetro estabelecidos pela Portaria do Ministério da Justiça e aqueles constantes do decreto presidência."

A argumentação do STF pode ser colhida no voto-vista do ministro Joaquim Barbosa que se reporta ao fato do procedimento para o reconhecimento das terras indígenas possuírem atos distintos $\mathrm{e}$ complementares. No caso, a Portaria tem como base levantamento preliminar, sendo este estudo que embasa a elaboração da Portaria. Contudo, posteriormente é feita a demarcação física da terra. Trata-se do 
momento em que se materializam os limites da terra indigena, dentro daqueles parâmetros postos inicialmente na portaria ministerial. Nessa fase de demarcação física, se os limites recaírem, por exemplo, sobre estradas e linhas secas (vale dizer, se o limite não incidir em acidente geográfico ou estrada), será necessária a realização de levantamento topográfico e geodésido, para implantação de marcos e placas indicativas.

Assim, como a precisa indicação das coordenadas geográficas e a definitiva medição da área só se dão em momento posterior ao da expedição da portaria - porque advêm, como resultado final, da demarcação física, na qual são apresentados cartografia internacional -, é natural que não haja perfeita correspondência entre aqueles parâmetros iniciais (constantes da já aludida portaria) e aqueles mencionados no decreto presidencial.

No caso da Terra Indígena Raposa Serra do Sol o STF manteve esse entendimento. O voto do ministro Direito para quem essa diferença: "trata-se de conseqüência possível da medição realizada após a fixação dos marcos e a atualização do mapa e do memorial descritivo.” Portanto, aqui também não assiste razão ao autor da Ação Popular.

\subsubsection{Fica vedada a ampliação da terra indígena já demarcada}

Ainda referente ao processo de demarcação uma das orientações com repercussão significativa para o futuro foi à proibição de ampliação de terras indígenas já demarcadas.

O STF levou em consideração mais uma vez a teoria do fato indígena, pois uma vez comprovado cientificamente os fatos não haverá mais espaço para revisão dessa área. Segundo o ministro Direito haveria preclusão administrativa. Exatamente por ter cumprido todas as exigências a partir de procedimentos regularmente instaurados, inclusive com observância do contraditório. Assim, após a homologação das terras indígenas resulta a consolidação de direitos individuais e/ou públicos. Sendo que esses direitos limitariam o da Administração Pública a uma aplicação absoluta do poderdever de revisão dos seus atos. Sustenta-se legalmente na Lei n. ${ }^{\circ}$ 9.784/99 e na Súmula n. ${ }^{\circ} 473$ do STF. 


\subsection{O Princípio da Unidade como a Base para Resolução do Caso da Terra Indigena Raposa Serra do Sol}

Para o ministro Menezes Direito a Constituição contempla uma pluralidade de interesses, que forma um todo unitário, fundamento de toda ordem jurídica e do sistema que não admite nem a instabilidade nem a autonegação (BRASIL, 2009, p. 405). O grande desafio, portanto, está na busca desse equilíbrio entre todos os interesses que o compõem.

Infere-se que o STF buscou uma interpretação orientado pelo princípio da unidade da Constituição onde não há valores superiores ou inferiores, mas complementares, buscando garantir ao mesmo tempo a proteção e preservação dos índios e da sua cultura e os interesse públicos de ordem nacional.

Nesse sentido, foi inovador na sua interpretação ao decidir criar um marco decisório ao estabelecer no dizer do Ministro Direito que:

Ao contrário do que sustentam alguns defensores de um caráter absoluto dos direitos indígenas, estes são, em verdade, uma das diversas expressões do interesse público de âmbito nacional. À nação brasileira interessa, sem dúvida, a proteção e a preservação dos interesses indígenas, mas interessa também a preservação do meio ambiente e da segurança de nossas fronteiras além de outros interesses públicos representados pela União, como prevê literalmente o art. 231 da Constituição da República. É importante identificar tais interesses para que o estatuto jurídico das comunidades indígenas possa ser de uma vez por todas definido considerando a disciplina constitucional. (BRASIL, p. 404)

Sendo esta a opção do STF que decidiu impor orientações a serem cumpridas não apenas referente a Terra Indígena Raposa Serra do Sol, mas como bem colocou o ministro Direito no seu voto: "A decisão adotada neste caso certamente vai consolidar o entendimento da Suprema Corte sobre o procedimento demarcatório com repercussão também para o futuro. Daí a necessidade do dispositivo explicitar a natureza do usufruto constitucional e seu alcance." 
Abaixo uma analise dos aspectos da decisão mais diretamente ligada as direito originário dos índios a terras ocupadas tradicionalmente, sem, contudo entrar nos aspectos do uso dos recursos ambientais.

\section{4.1. Terras Indigenas Sobrepostas a Faixas de Fronteiras}

Esta decisão referente às terras indígenas localizadas em faixas de fronteiras terá grande repercussão no Estado brasileiro, pois hoje cento e oitenta e sete (187) terras indígenas estão localizadas nessas faixas, correspondente a 57,64\% da área total de faixa de fronteiras no Brasil que é de $1.420 .616,188 \mathrm{~km}^{2}$.

O STF considerou a possibilidade de afetação dupla ou até tripla em terras públicas, como foi o caso das sobreposições da Terra Indígena Raposa a Serra do Sol que está integralmente localizada em área considerada faixa de fronteira e também tem uma parte localizada em Unidade de Conservação Federal. A base da argumentação utilizada pelo STF está no fato da terra indígena tratar-se de bem da União, conforme previsão do art. 20, inciso da $\mathrm{CF} / 88$. E, cuja afetação está destinada aos índios sem que isto exclua o interesse público.

O STF buscou orientar-se pelo princípio da unidade da Constituição, porquanto de um lado temos a necessidade de garantir a proteção e preservação dos índios e da sua cultura e, de outro, a proteção dos interesses da defesa nacional. No caso específico da Terra Indígena Raposa Serra do Sol o usufruto exclusivo dos índios sobre a terra indígena estará sujeito as restrições sempre que o interesse público de defesa nacional estiver em jogo.

Os ministros não vislumbraram conflitos reais, mas tão somente aparentes. Segundo o entendimento do STF nada impede a convivência pacífica dos povos indígenas e daqueles responsáveis pela proteção do Estado brasileiro. Em alguns casos, chegam a citar a importância da presença indígena nessas faixas como bravos combatentes a invasores das nossas fronteiras. Além disso, ressaltam que o Brasil possui um único território a ser protegido para todos os brasileiros independente de serem indios, negros, brancos. 
No caso específico da terra indígena raposa serra do sol questionou-se a necessidade de consulta ao Conselho de Defesa Nacional (CDN). Contudo, o STF considera que a Constituição de 88 foi clara ao dispor que o CDN é órgão consultivo, não há, portanto que se falar em assentimento prévio.

A discussão então recairia quanto à necessidade da oitiva do CDN. O ministro Brito comenta que alguns defendem não haver essa necessidade, pois a constituição já teria colocado todos os critérios e condições para utilização dessas áreas. Contudo, não é esse o entendimento do ministro para quem a constituição previu casos em que as faixas de fronteiras tivessem outras afetações. E conclui "não havendo ressalvas por parte da Constituição, não seria cabível diferenciar as terras indígenas de outras áreas no que se refere às restrições e peculiaridades a faixa de fronteira.” (BRASIL, 2009, p. 402).

\subsubsection{Terras Indigenas Sobrepostas a Unidades de Conservação Federal}

O caso da terra indígena Raposa Serra do Sol também trouxe orientações para procedimentos quando houver coincidência entre terras indígenas e unidades de conservação. Mais uma vez destacamos dados estatísticos trazido no corpo do acórdão (BRASIL, 2009), mais precisamente no voto do ministro Brito que nos informa serem quarenta e cinto (45) as terras indígenas com áreas que coincidem com unidades de conservação federais. Essas áreas equivalem a 8,77\% do total das áreas indígenas.

O STF também considerou tratar-se de conflito aparente. As unidades de conservação assim como as terras indígenas recebem proteção constitucional. Há muito os pesquisadores se debruçam sobre o tema da conciliação entre terras indígenas e unidades de conservação. Porém, o ministro Brito critica as propostas apresentadas pelos pesquisadores, ao apontar falta de objetividade e concretude nas mesmas, além de não indicarem quais restrições seriam necessárias ao usufruto exclusivo dos índios para se chegar a uma conciliação.

Para conciliar é imprescindível se afastar toda e qualquer forma de radicalismo. Foi esta a linha seguida pelo STF, para retirar orientações a 
serem seguidas sempre que houver coincidência de terras indígenas e unidades de conservação.

A primeira orientação é da permissibilidade de dupla afetação, indicando que não se deve falar em exclusão de áreas, mas da conciliação entre as mesmas. A segunda orientação, que a administração da unidade de conservação deverá ficar sob a responsabilidade do ICMBIO, sempre que necessário ouvindo os índios e a FUNAI. Por tratar-se de meio ambiente, considerado um bem de todos e de toda a humanidade. Limitando inclusive aspectos culturais, como por exemplo, impondo o período para o desenvolvimento de algumas das suas atividades de extrativismo vegetal.

\subsubsection{Quanto ao Poder Público}

Assegurou a atuação das forças armadas e da polícia federal na área indígena, no âmbito de suas atribuições. Nesse caso, independentemente de consultas às comunidades indígenas envolvidas ou à FUNAI.

Informou que o usufruto indígena não impede a instalação, pela União Federal, de equipamentos públicos, redes de comunicação, estradas e vias de transporte, além das construções necessárias à prestação de serviços públicos pela União, especialmente os de saúde e educação.

\subsubsection{Referente aos Não-Índios}

O STF admitiu que os não-índios poderão transitar tanto nas áreas com dupla afetação, nesse caso consideradas além de terras indígenas como unidades de conservação; como no restante das terras indígenas.

Quando as visitas incidirem nas terras indígenas onde está localizada a unidade de conservação quem irá autorizar as mesmas será o ICMBIO. E, referente às visitas no restante da área será autorizada pela FUNAI.

O STF também considerou que não poderá haver cobrança de quaisquer tarifas ou quantias de qualquer natureza por parte das comunidades indígenas: a) para o ingresso, o trânsito e a permanência de não-índios; b) em troca da utilização das estradas, equipamentos públicos, 
linhas de transmissão de energia ou de quaisquer outros equipamentos e instalações colocadas a serviço do público, tenham sido excluídas expressamente da homologação, ou não.

\section{Conclusão}

Ao término de nossa analise, constatamos ter havido um esforço muito

98 grande por parte dos ministros do STF no sentido de buscar o enfrentamento de por restrições aos direitos dos povos indígenas no que diz respeito aos seus territórios.

Inicialmente procuramos demonstrar a possibilidade do uso dos vocábulos "povos" e "territórios" relacionados aos índios, desde que utilizados com base na antropologia. Inclusive procuramos demonstrar que mesmo a Constituição não tendo feito referência explicita aos termos é possível identificá-los. Além disso, há diplomas legais que fazem referência aos mesmos, como a Convenção 169 da OIT e o Decreto n. ${ }^{\circ}$ 6.040/07. Também verificamos no acórdão analisado que muitos ministros fizeram referência ao termo "território".

O STF inovou com a teoria dos fatos aprofundando a teoria dos círculos concêntricos. Esta teoria indicou não só a possibilidade de verificação cientifica das terras tradicionalmente ocupadas pelos índios, mas dispensou considerações sobre a ocupação imemorial, porquanto não basta apenas ter sido ocupada, mas permanecer ocupada na data da promulgação da Constituição Federal de 88, nesse sentido o ministro Direito propôs que o STF passe a adotar como critério constitucional não a teoria do indigenato, mas a do fato jurídico.

Ao analisar a Convenção n. ${ }^{\circ} 169$ não vislumbramos incompatibilidade com a nossa Constituição, ao contrário se coaduna com a mesma na garantia do direitos dos povos indigenas e algumas situações e a Constituição consegue ser criativa na proteção desses direitos sem que necessariamente esteja seguindo o instituto indicado pela mesma. É o caso quando a Convenção diz que devemos reconhecer o direito de propriedade e

posse dos territórios aos povos indígenas. E, a Constituição prevê a 
propriedade como sendo da União e a posse permanente dos índios, contudo referidas áreas são destinadas aos povos indígenas e são indisponíveis e inalienáveis e, os direitos sobre elas imprescritiveis. Atendo, portanto a essência da Convenção, qual seja, garantir o reconhecimento do direito originário as terras tradicionalmente ocupadas pelos índios.

Ao analisar as normas infraconstitucionais que garantem o reconhecimento dos povos indígenas identificamos o Estatuto do Índio, o Decreto n. ${ }^{\circ}$ 6.040/07. Contudo, o verdadeiro reconhecimento com indicação dos institutos de proteção vem da própria Constituição Federal.

Os institutos disponiveis para o reconhecimento de territórios aos povos indígenas são o direito originário as terras tradicionalmente ocupadas pelos índios, a posse permanente e o usufruto indígena. Todos conforme ressaltado alhures de origem constitucional, com base no direito coletivo e, capazes de atender a garantia do reconhecimento do direito aos seus territórios.

Os procedimentos para identificação, demarcação, homologação das terras indígenas são claros, contudo ganharam maior clareza após a decisão do STF referente à Ação Popular n. ${ }^{\circ}$ do caso da Terra Indígena Raposa Serra do Sol. Essa decisão trouxe como base a teoria do fato indígena que além de ressaltar os elementos imprescindiveis à definição das terras tradicionalmente ocupadas pelos índios, trabalhados na teoria dos círculos concêntricos, indicou que esses elementos são fatos a serem analisados por métodos científicos da antropologia e estudados por equipe multidisciplinar para que possa aferir se estamos ou não diante de uma terra indígena. E, mais não trata apenas de saber se as mesmas foram ocupadas no passado pelos índios, mas permanecem ocupadas na data da promulgação da Constituição Federal. Indicando a superação da teoria do indigenato pela teoria do fato quando o STF desejar identificar se a terra é ou não indígena.

Guanto às contribuições da decisão do STF referente à Ação Popular do Caso da Terra Indígena Raposa Serra do Sol a principal foi o enfrentamento da questão dos direitos indígenas e da necessidade de conciliá-los ao demais interesses da nação. A utilização do princípio da unidade como base para a decisão no sentido de conciliar e não expurgar 
direitos. Ao permitir três afetações em uma mesma área pública, buscando respeito mútuo em razão da imprescindivel necessidade ora de resguardar nosso país, ora de resguardar bem de interesse difuso e pertencente a toda coletividade.

Verificamos que embora os povos indígenas recebam proteção especial por parte da Constituição Federal, a decisão do STF poderia não poderia ser simplista, e considerar algum interesse em detrimento de outro. A forma como foi tratado o tema sempre, como não poderia deixar de ser, com base na interpretação da Constituição como lei mãe, permitiu aos ministros um novo olhar referente à necessidade de conciliar interesses da nação, orientando quando necessárias restrições, sempre no sentido de buscar com base no princípio da unidade o equilíbrio que faltava para essa relação de unidade de todos os interesses.

\title{
RECOGNITION OF THE RIGHT TO INDIANS ON THE ORIGIN LANDS THEY TRADITIONALLY OCCUPY: RAPOSA SERRA DO SOL
}

\begin{abstract}
This study deals with indigenous issues in order to do a comparative analysis and critique of legal rules on the recognition of the territorial rights of indigenous peoples by reference to the case of the Raposa Serra do Sol, judged by the Supreme Court of Brazil (STF) The methodological approach was based on a theoretical research with literature, doctrinal, legal, of international conventions and national literature. The results indicate a clash of the Supreme Court of indigenous rights based on the principle of unity. Interpretations resulted in a new look regarding the need to reconcile the interests of the nation, guiding when necessary restrictions.
\end{abstract}

Keywords: Indigenous Peoples. Environment. Environmental heritage culture. Raposa Serra do Sol.

\section{Notas explicativas}

\footnotetext{
${ }^{1}$ Utilizamos neste estudo lei em sentido formal e material. Meirelles informa que os atos normativos não são lei em sentido formal, mas são em sentido material. Explica: são "[...] provimentos executivos com conteúdo de lei. [...] por serem gerais e abstratos, têm a mesma normatividade da lei e a ela se equiparam para fins de controle judicial [...]" (MEIRELLES, 1990, p.158).
} 
2 Para Alexy (1977), o sistema jurídico é composto por princípios e regras, ambos considerados como. Adota-se essa posição no presente estudo.

3 A Lei n. ${ }^{\circ}$ 10.406, de 2002, em seu artigo 1.196, define possuidor como "[...] todo aquele que tem de fato o exercício, pleno ou não, de algum dos poderes inerentes à propriedade”. Os poderes da propriedade são usar, gozar, dispor da coisa e reivindicá-la. Dessa forma, quem exerce um ou alguns desse poderes será considerado possuidor (BRASIL. Lei n. ${ }^{\circ}$ 10.406, de 10 de janeiro de 2002. Diário Oficial [da] República Federativa do Brasil, Brasília, DF, 11 jan. 2002e. Disponível em: <http://www.planalto.gov.br/ccivil_03/LEIS/2002/L10406.htm>. Acesso em: 12 jun. 2009).

${ }^{4}$ Assim definida por Mattos Neto: "[...] o exercício direto, contínuo, racional e pacífico de atividades agrárias (propriamente ditas, vinculadas ou complementares, e conexas) desempenhadas em gleba de terra rural capaz de dar condições suficientes e necessárias ao seu uso econômico, gerando ao possuidor um poder jurídico de natureza real definitiva com amplas repercussões no Direito, tendo em vista o seu progresso e bem-estar econômico e social" (MATTOS NETO, Antonio José de. Posse agrária e suas implicações jurídicas no Brasil. Belém: CEJUP, 1988, p. 68).

5 No dizer de Santilli, esses direitos são "[...] congênitos, legítimos por si, [...] não se confundem com direitos adquiridos” (SANTILLI, J., 1999, p. 45).

6 De acordo com Silva, a referência à posse permanente na Constituição Federal constitui uma garantia para o futuro, porquanto as áreas são destinadas para sempre aos povos indigenas, tornando-se inalienáveis e indisponiveis. Para o autor, a posse permanente resulta de um direito preexistente à posse mesma - o direito originário (SILVA, José Afonso da. Terras tradicionalmente ocupadas pelos índios. In: SANTILLI, Juliana (Org.). Os direitos indigenas e a Constituição. Porto Alegre: Sergio Antonio Fabris, 1993. p. 45-50).

7 Aqui nos referimos às categorias de terras públicas previstas na Lei $n .^{\circ}$ 10.406/02, em seu artigo 99, incisos de I a III: bens de uso comum do povo, bens de uso especial e bens dominicais (BRASIL, 2002e).

\section{Referências}

ALEXY, Robert. El concepto y la validez del derecho. Barcelona: Gedisa, 1977. 
ALMEIDA. Alfredo Wagner Berno de. Terras de quilombo, terras indigenas, 'babaçuais livres', 'castanhais do povo', faixinais e fundos de pasto: terras tradicionalmente ocupadas. Manaus: PPGSCA-UFAM, 2006.

ALTO COMISSARIADO DAS NAÇÕES UNIDAS PARA OS DIREITOS HUMANOS. Os direitos das minorias. Lisboa: Gabinete de Documentação e Direito Comparado da Procuradoria Geral da República, out. 2008. Ficha informativa sobre direitos humanos, n. 18. Anexo I, p. 28. Década das Nações Unidas para a Educação em matéria de direitos humanos 1995/2004. Edição portuguesa. Disponível em: <http://www.gddc.pt/direitos-humanos/Ficha_18.pdf>. Acesso em: 23 maio 2009.

ANTUNES, Paulo de Bessa. Ação civil pública, meio ambiente e terras indigenas. Rio de Janeiro: Lumen Juris, 1998, p. 139-140.

BENATTI, José Heder. Posse agroecológica e manejo florestal. Curitiba: Juruá, 2003.

BRASIL. Lei n. ${ }^{\circ}$ 6.001, de 19 de dezembro de 1973. Diário Oficial [da] República Federativa do Brasil, Brasília, DF, 21 dez. 1973. Disponível em: <http://www.planalto.gov.br/ccivil/leis/16001.htm>. Acesso em: 18 maio 2009.

BRASIL. Constituição da República Federativa do Brasil, de 5 de outubro de 1988. Diário Oficial [da] República Federativa do Brasil, Brasília, DF, 5 out. 1988a. Disponivel em: <http://www.planalto.gov.br/ccivil_03/constituicao/constitui\%C3\%A7ao.ht m>. Acesso em: 24 maio 2009.

BRASIL. Decreto n. ${ }^{\circ}$ 592, de 6 de julho de 1992. Diário Oficial [da] República Federativa do Brasil, Brasília, DF, 7 jul. 1992. Disponível em: <http://www6.senado.gov.br/legislacao/ListaTextoIntegral.action?id=1 14187>. Acesso em: 22 maio 2009.

BRASIL. Decreto n. ${ }^{\circ}$ 1.775, de 8 de janeiro de 1996. Diário Oficial [da] República Federativa do Brasil. Brasília, DF, 9 jan. 1996a. Disponível em: <http://www.planalto.gov.br/ccivil_03/decreto/D1775.htm>. Acesso em: 23 maio 2009.

BRASIL. Lei n. ${ }^{\circ}$ 10.406, de 10 de janeiro de 2002. Diário Oficial [da] República Federativa do Brasil, Brasília, DF, 11 jan. 2002e. Disponivel em: <http://www.planalto.gov.br/ccivil_03/LEIS/2002/L10406.htm>. Acesso em: 12 jun. 2009.

BRASIL. Decreto n. ${ }^{\circ} 5.051$, de 19 de abril de 2004. Diário Oficial [da] República Federativa do Brasil, Brasília, DF, 20 abr. 2004a. Disponível em: 
<http://www.planalto.gov.br/ccivil_03/_ato2004-

2006/2004/decreto/d5051.htm >. Acesso em: 30 jul. 2009.

BRASIL. Decreto n. ${ }^{\circ}$ 6.040, de 7 de fevereiro de 2007. Diário Oficial [da] República Federativa do Brasil, Brasília, DF, 8 fev. 2007a. Disponível em: <http://www.planalto.gov.br/ccivil_03/_Ato2007-

2010/2007/Decreto/D6040>. Acesso em: 28 nov. 2008.

BRASIL. Decreto n. ${ }^{\circ}$ 6.040, de 7 de fevereiro de 2007. Diário Oficial [da] República Federativa do Brasil, Brasília, DF, 8 fev. 2007a. Disponível em: <http://www.planalto.gov.br/ccivil_03/_Ato2007-

2010/2007/Decreto/D6040>. Acesso em: 28 nov. 2008.

BRASIL. Supremo Tribunal Federal. Ação Popular Pet. n. ${ }^{\circ}$ 3388-RR. Relator Carlos Britto. Julgamento em: 3 abr. 2009. DJ, n. 071, 17 abr. 2009.

CAVALCANTE FILHO, João Trindade. Usufruto exclusivo das terras indígenas: natureza jurídica, alcance e objeto. Jus Navigandi, Teresina, ano 12, n. 1640, 28 dez. 2007. Disponivel em: <http://jus2.uol.com.br/doutrina/texto.asp?id=10804>. Acesso em: 26 maio 2009.

DIEGUES, Antonio Carlos. Água e cultura nas populações tradicionais brasileiras. 2007, p. 6. Trabalho apresentado no I Encontro Internacional: Governança da Água, São Paulo, nov. 2007. Disponível em: <http://www.usp.br/nupaub/simbolagua.pdf>. Acesso em: 9 dez. 2008.

FIORILLO, Celso Antonio Pacheco; RODRIGUES, Marcelo Abelha. Manual de direito ambiental e legislação aplicável. São Paulo: Max Limonad, 1997.

INSTITUTO NACIONAL DE COLONIZAÇÃO E REFORMA AGRÁRIA (Brasil). Portaria n. ${ }^{\circ}$ 627, de 30 de julho de 1987. Disponível em: <http://www.incra.gov.br/portal/arquivos/legislacao/0976303126.pdf>.

Acesso em: 12 maio 2009.

LITTLE, Paul E. Territórios sociais e povos tradicionais no Brasil: por uma antropologia da territorialidade. Brasília, DF, 2002 (Série Antropologia, n. 322). Disponível em: <http://www.unb.br/ics/dan/Serie322empdf.pdf>. Acesso em: 23 maio 2009.

MAIA, Luciano Mariz. Comunidades e organizações indígenas: natureza jurídica, legitimidade e outros aspectos jurídicos. In: SANTILLI, Juliana (Org.). Os direitos indígenas e a Constituição. Porto Alegre: Núcleo de Direitos Indígenas; Sergio Antonio Fabris, 1993.

MATTOS NETO, Antonio José de. Posse agrária e suas implicações jurídicas no Brasil. Belém: CEJUP, 1988. 
MEIRELLES, Hely Lopes. Direito administrativo brasileiro. 23. ed. atual. por Eurico de Andrade Azevedo, Délcio Balestero Aleixo e José Emmanuel Burle Filho. São Paulo: Malheiros, 1990.

MENDES, Artur Nobre. Reconhecimento das terras indígenas: situação atual. In: GRAMKOW, Márcia Maria (Org.). Demarcando terras indigenas II: experiências e desafios de um projeto de parceria. Brasília, DF: FUNAI; PPTAL; GTZ, 2002.

OLIVEIRA FILHO, João Pacheco. Terras indígenas: uma avaliação preliminar de seu reconhecimento oficial e de outras destinações sobrepostas. In: PACHECO, João; RICARDO, Carlos Alberto (Org.).Terras Indigenas no Brasil. São Paulo: CEDI, 1987, p. 9, grifos nossos).

PEREIRA, Deborah Macedo Duprat de Britto. Mesa I: Os fundamentos jurídicos da titulação das terras de quilombos. In: OLIVEIRA, Leinad Ayer de (Org.). Quilombos: a hora e a vez dos sobreviventes. São Paulo: Comissão Pró-Índio de São Paulo, 2001.

REZEK, José Francisco. Direito internacional público: curso elementar. 9. ed. rev. São Paulo: Saraiva, 2002.

SANTILLI, Juliana. Socioambientalismo e novos direitos. São Paulo: Petrópolis, 2005.

SANTILLI, Juliana. A proteção jurídica às terras indígena e a seus recursos naturais. In: KASBURG, Carola; GRAMKOW, Márcia Maria (Org.). Demarcando terras indigenas: experiências e desafios de um projeto de parceria. Brasília, DF: FUNAI; PPTAL; GTZ, 1999.

SANTILLI, Márcio. Natureza e situação da demarcação das terras indígenas no Brasil. In: KASBURG, Carola; GRAMKOW, Márcia Maria (Org.). Demarcando terras indigenas: experiências e desafios de um projeto de parceria. Brasília, DF: FUNAI; PPTAL; GTZ, 1999, p. 23).

SILVA, José Afonso da. Terras tradicionalmente ocupadas pelos índios. In: SANTILLI, Juliana (Org.). Os direitos indigenas e a Constituição. Porto Alegre: Sergio Antonio Fabris, 1993.

SILVA, José Afonso da. Curso de direito constitucional positivo. 16. ed., rev. e atual. São Paulo: Malheiros, 1999.

SOUZA FILHO, Carlos Frederico Marés de. O renascer dos povos indigenas para o direito. Curitiba: Juruá, 1999.

SUNDFELD, Carlos Ari (Org.). Comunidades quilombolas: direito à terra. Brasília, DF: Fundação Cultural Palmares; MinC; Editorial Abaré, 2002 
TOURINHO NETO, Fernando da Costa. Os direitos originários dos índios sobre as terras que ocupam e suas conseqüências jurídicas. In: SANTILLI, Juliana (Org.). Os direitos indigenas e a Constituição. Porto Alegre: Núcleo de Direitos Indígenas; Sergio Antonio Fabris, 1993.

Artigo submetido para avaliação em 05 de maio de 2013 e aceito para publicação em 12 de agosto de 2013. 